\title{
Dlaczego nie ma taśm z powstania wielkopolskiego?
}

\author{
MAREK HENDRYKOWSKI \\ Instytut Filmu, Mediów i Sztuk Audiowizualnych \\ Uniwersytet im. Adama Mickiewicza w Poznaniu
}

\begin{abstract}
Hendrykowski Marek, Dlaczego nie ma taśm z powstania wielkopolskiego? [Why there is no film reels from Wielkopolska Uprising of 1918-1919?]. “Images” vol. XXIX, no. 38. Poznań 2021. Adam Mickiewicz University Press. Pp. 265-273. ISSN 1731-450X. DOI 10.14746/i.2021.38.17.

The article is a monographic study of the moving picture of Wielkopolska Uprising 1918-1919. The author indicates the reasons of a lack of film archives concerning Posnanian War.

KEYwORDs: history, Wielkopolska Uprising 1918-1919, Józef Piłsudski, Ignacy Jan Paderewski, film, documentary, iconography, filmography, film archive, representation, image, reconstruction
\end{abstract}

\section{Wprowadzenie}

Współcześni Polacy wiedzą na temat powstania wielkopolskiego - nie tak przecież odległego w czasie - znacznie mniej, niżby ono samo na to historycznie zasługiwało. Wystarczy przeprowadzić prosty test historyczno-geograficzny zawierający pytanie o miasta i miejscowości tej części ziem polskich, które znalazły się lub nie w granicach II Rzeczypospolitej. Poznań, Gniezno, Września, Kórnik, Środa, Miłosław, Chodzież, Kościan, Krotoszyn, Pleszew, Ostrów Wielkopolski, Buk, Dolsk, Ostrzeszów, Kępno, Mątwy, Janikowo, Inowrocław?

Oczywiście tak, to wiadomo powszechnie. Ale idźmy dalej: Bydgoszcz (owszem, tak, lecz od kiedy?), Leszno, Rawicz, Chełmno, Chełmża, Toruń - podobnie jak Bydgoszcz. A Sieraków, Pniewy, Zbąszyń, Mieszków, Budzyń, Zbąszynek, Grodzisk Wielkopolski, Wolsztyn, Przemęt, Włocławek, Sieraków, Międzychód, Trzcianka, Skwierzyna, Książ, Kargowa, Wronki, Czarnków, Kluczbork, Ujście, Piła, Krzyż, Dobiegniew, Gorzów Wielkopolski, Szubin, Kcynia, Wschowa, Trzciel, Chojnice, Nakło, Więcbork, Babimost, Wałcz, Brodnica, Świecie nad Wisłą, Brodnica, Tczew, Pelplin, Zielona Góra, Żary, Żagań, Nowa Sól, Grudziądz, Szczecinek, Miasteczko, Żmigród, Ciechocinek, Koronowo, Gostyń, Syców?
Celowo zmieszałem tutaj z sobą dwa porządki miast: jeden na tak, drugi na nie. Zakładam przy tym, że w stosunku do niejednego $\mathrm{z}$ wywołanych tu haseł może pojawić się dzisiaj niemały problem $\mathrm{z}$ właściwą odpowiedzią. Granica w Wielkopolsce i na Pomorzu, podobnie jak na Górnym Śląsku, tworzyła się stopniowo przez kilka lat i w sposób częstokroć dramatyczny, a niekiedy wręcz kuriozalny w swym meandrycznym (przykładem Zbąszyń, granica Leszno-Wschowa, Piła, Bytom, Huta Królewska etc.) przebiegu.

\section{Horyzont refleksji}

$\mathrm{Na}$ początek spróbujmy określić zakres przedmiotowy i kryteria naszego zainteresowania. Tytuł sugeruje, iż w grę z założenia nie wchodzą żadne fabularyzowane rekonstrukcje i współczesne przedstawienia ekranowe, umownie nazywane „obrazami”, wydarzeń powstania wielkopolskiego. Generalnie nie są one przedmiotem tego studium, zatem nie zostaną w nim szerzej uwzględnione i jako filmowy artefakt nie będą dla potrzeb tych rozważań satysfakcjonujące.

Owszem, pochodzące $\mathrm{z}$ różnego okresu ekranowe prezentacje powstania wielkopolskiego, operujące na kanwie jego wydarzeń fikcją, jak i obrazy rekonstrukcyjne o charakterze pa- 
radokumentalnym, istnieją. Nie sposób jednak twierdzić, że namnożyło się ich przez lata przesadnie wiele. Niemniej, szereg zrealizowanych filmów zasługuje w tym miejscu na przywołanie.

Do przedstawień tych należą: ostatni, trzynasty odcinek Najdłuższej wojny nowoczesnej Europy, zatytułowany Zwycięstwo bez wodzów (reż. Jerzy Sztwiertnia, 1981), piąty i szósty odcinek miniserialu Republika Ostrowska (pod tytułem Republika Ostrowska i Noc sylwestrowa, reż. Zbigniew Kuźmiński, 1985), kinowa wersja tego filmu pt. Republika nadziei (reż. Zbigniew Kuźmiński, 1986), poświęcone w całości tematowi powstania wielkopolskiego Męskie sprawy w reżyserii Jana Kidawy-Błońskiego (1988), Zapomniane powstanie Krzysztofa Magowskiego (2008), a ostatnio wielkospektaklowa Hiszpan$k a$ w reżyserii Łukasza Barczyka (2015).

Należy dodać, iż powstanie wielkopolskie było również parokrotnie inscenizowane: bądź w charakterze rekonstrukcji przebiegu jednego z epizodów powstańczych, bądź też jako fragment panoram historycznych ukazujących odzyskanie niepodległości i dzieje II Rzeczypospolitej. W obu tych kategoriach mieszczą się: wyprodukowana przez Zespół Filmowy „Profil” Polonia Restituta (wersja kinowa i serial telewizyjny, 1980-1982) w reżyserii Bohdana Poręby, Powstanie Wielkopolskie. Zdobycie Ławicy (reż. Janusz Sidor[1], 2008), Powstanie Wielkopolskie. Nowe Ateny (reż. Maciej Sawicki, prod. Telewizja Polska Poznań, 2015), Mieczysław Paluch: człowiek, powstaniec, dowódca (reż. Janusz Sidor, 2015) oraz trzyczęściowa rekonstrukcja historyczna zatytułowana: Powstanie Wielkopolskie. Most na Noteci; Powstanie Wielkopolskie. Czarnków odzyskany oraz Powstanie Wielkopolskie. Bitwa o Chodzież (reż. Paweł Różycki, prod. TV ASTA, 2018). Powyższe tytuły wymieniam jednak w tym sumarycznym zestawieniu wyłącznie z filmograficznego obowiązku ich odnotowania.

[1] Dokumentalista Janusz Sidor jest również autorem filmowego portretu dokumentalnego jednej ze znaczących postaci powstania: Mieczysław Paluch. Człowiek, powstaniec, dowódca (prod. Sidma, 2015).
O tym, że historiografię dzielnicową oraz geografię polityczną walk o odzyskanie przez Polskę niepodległości po I wojnie światowej cechuje perspektywa warszawska, a w niej akcent położony zdecydowanie na terytoria wschodnie, a nie zachodnie czy północne (wyjąwszy Wilno), nie trzeba nikogo specjalnie przekonywać. Ślązacy, Wielkopolanie i Pomorzanie nieprzypadkowo mają, uzasadniony skądinąd, żal o traktowanie ich wysiłków, owocnych dążeń oraz niezmiernie doniosłego niepodległościowego wkładu w sposób marginalny i dość obojętny.

Zmiana w tej kwestii, choć w ostatnim czasie zauważalna, dokonuje się bardzo powoli. Nie chodzi przecież tylko o jakąś pojedynczą wzmiankę poczynioną na marginesie ukazywania wielkich dziejów walki o niepodległość, lecz o rzetelne przedstawienie owego wkładu: zauważalne w świadomości nie tylko samych Wielkopolan, lecz ogółu Polaków. Mamy tu na uwadze coś o wiele istotniejszego, mianowicie zasadniczą rewizję oceny propor cji historycznego wkładu. W materii opisu, analizy i interpretacji wydarzeń historycznych zauważyć bowiem sam fakt, a ocenić jego znaczenie i uznać doniosłą wagę - to, było nie było, przepastna różnica.

Taśm filmowych dokumentujących ówczesne wydarzenia w prowincji poznańskiej prawie nie ma. Wypada postawić pytanie: dlaczego w przypadku Poznania i Wielkopolski tak się stało? Czy ziemie polskie pod zaborem pruskim w tamtym dramatycznym okresie, gdy żadna z naszych granic $z$ sąsiadami na wschodzie, zachodzie, północy i na południu nie mogła zostać uznana za ustaloną i stuprocentowo pewną, $z$ góry uznano $w$ obu innych zaborach za niemożliwe do odzyskania i włączenia $\mathrm{w}$ granice odradzającego się państwa polskiego?

A może raczej zdecydowała zorientowana na walkę przeciw potędze Rosji najpierw w oparciu o Austro-Węgry, a po kryzysie przysięgowym Niemcy, strategia wojenna Piłsudskiego? Czy istotnie jego nastawienie wobec Wielkopolski w pierwszej fazie powstania stało się przyczyną pewnej niechęci, jeśli nie nawet animozji, między Poznańczykami a Naczelnikiem Pań- 
stwa? Być może właśnie ono przesądziło o nader chłodnych relacjach, które sprawiły, że w następnych kilkunastu latach zachodnia część kraju była miejscem przez niego rzadko odwiedzanym.

\section{Piłsudski a Wielkopolska}

Jest kwestią otwartą i wielce dyskusyjną, czy Józef Piłsudski wierzył, czy całkiem nie wierzył w możliwość powrotu Górnego Śląska, Poznania z Wielkopolską i Gdańska z Pomorzem do rodzącej się na nowo Polski. Nie ulega jednak wątpliwości, że powstaniem w Wielkopolsce jako przywódca zainteresował się nie w trybie udzielenia mu wszelkiej natychmiastowej pomocy, lecz dopiero po dłuższym czasie, działając bardzo wstrzemięźliwie i przyglądając się z perspektywy Warszawy rozwojowi wypadków.

Pozostaje natomiast rzeczą bezsporną, że dla wsparcia samego powstania uczynił niewiele. Brakowało konkretnych decyzji i działań. Przywołany tytuł odcinka Najdłuższej wojny nowoczesnej Europy - „Zwycięstwo bez wodzów" - nie wydaje się jakoś szczególnie retorycznie naciągnięty w kontekście faktu, że $\mathrm{w}$ pierwszych tygodniach powstaniem wielkopolskim dowodził nie generał, lecz świeżo mianowany major[2].

Czy znak zapytania wokół tego, jak i czym skończy się powstańczy zryw Wielkopolan w końcu grudnia 1918, był aż tak wielki? Naczelnik Państwa doskonale zdawał sobie sprawę ze znikomości sił i środków, jakimi dysponowali na samym początku powstańcy, i z tego, jak wielką potęgą militarną mimo wszystko pozostaje armia niemiecka, pokonana niedawno na frontach Wielkiej Wojny.

Sporo do myślenia daje fakt, że nie poparł oficjalnie powstania w Wielkopolsce, co Poznańczycy i Wielkopolanie komentowali jednoznacznie jako widomy dowód sekretnego porozumienia zawartego przez Piłsudskiego z Niemcami (mowa o poufnych rozmowach $\mathrm{z}$ hrabią Harrym Kesslerem, przedstawicielem niemieckiego MSZ, a wkrótce po zakończeniu wojny pierwszym ambasadorem Niemiec w Warszawie) w okresie poprzedzającym listopadowy przyjazd do Warszawy. Nasuwa się pytanie, czy przedmiotem kontraktu mogła być zawarta wówczas ugoda co do zachowania status quo w Wielkopolsce, na Śląsku i na Pomorzu w zamian za uwolnienie z półtorarocznego internowania w Magdeburgu.

Rozważając tę ewentualność, opieramy się jednak głównie na domysłach, a nie na udokumentowanych źródłowo faktach. Jedno w tym wszystkim wydaje się niewątpliwie pewne. To mianowicie, iż priorytetem politycznym Warszawy była nie zachodnia, lecz wschodnia granica przyszłego państwa. To ją przede wszystkim należało zbrojnie wywalczyć i to na niej koncentrowało się zainteresowania wodza, sztabu generalnego i wszelkie wysiłki oraz prowadzone w latach 1918-1920 działania wojenne. Z Wielkopolanami nie było Piłsudskiemu po drodze i mieszkańcy tych ziem pamiętali mu do samego końca traktowanie ich po macoszemu.

Warto w tym miejscu zauważyć, iż ponownie zabrakło obecności Piłsudskiego na początku marca 1919 roku, kiedy przyjechała do Poznania międzynarodowa Misja Koalicyjna, w skład której wchodzili między innymi: dyplomata, ambasador Joseph Noulens oraz bohater zakończonej niedawno wojny, jeden z najważniejszych dowódców armii francuskiej, generał Henri Albert Niessel, a także oficerowie włoscy i brytyjscy. Pobyt przedstawicieli misji

[2] Pierwszym głównodowodzącym powstania wielkopolskiego był b. kapitan piechoty Armii Cesarstwa Niemieckiego inż. Stanisław Taczak (1874-1960), promowany w imieniu Naczelnej Rady Ludowej przez przebywającego w Poznaniu w momencie wybuchu powstania Wojciecha Korfantego na stopień majora. Warto również odnotować w tym miejscu niemal zapomnianą dzisiaj, rzadko przywoływaną w podręcznikach historii postać innego dowódcy, bohatera powstania wielkopolskiego i II powstania śląskiego kapitana Mieczysława Palucha (1888-1942). Zaprzysiężenie żołnierzy powstańczej Armii Wielkopolskiej pod dowództwem gen. Józefa Dowbora-Muśnickiego odbyło się na dawnym placu Wilhelma w Poznaniu, uwaga! bez obecności Naczelnika Państwa, miesiąc po przybyciu Paderewskiego i wybuchu powstania, 26 stycznia 1919 roku. 
alianckiej w dniach 1-3 marca 1919 roku, a więc tuż po zakończeniu powstania wielkopolskiego, zarejestrował kamerą Jan Skarbek-Malczewski. Wspomnianego materiału filmowego - wolno przypuszczać: reprezentującego w chwili obecnej znaczną wartość historyczną - nie udało się dotąd odnaleźć ani w zbiorach krajowych, ani w żadnym z europejskich archiwów[3].

Całkowicie nieprawdziwe jest natomiast twierdzenie, że w związku $\mathrm{z}$ niechętną jego osobie aurą wyczuwalnej rezerwy w tamtejszych kręgach Józef Piłsudski nigdy już nie pojawił się w Poznaniu i Wielkopolsce. Dzięki źródłowym badaniom historyków - profesorów UAM - Andrzeja Kwileckiego, Stanisława Sierpowskiego, Zbigniewa Dworeckiego i Artura Kijasa wiemy dzisiaj na ten temat znacznie więcej niż niegdyś. Owszem, Józef Piłsudski jako Naczelnik Państwa bywał w Poznańskiem i to niejeden raz. Spróbujmy, opierając się na faktach, zrelacjonować pokrótce wszystkie te pobyty, mając na uwadze zmienny kontekst społeczno-polityczny, a także militarny, jaki towarzyszył każdemu z nich.

27 maja 1919 roku w Kaliszu odbyło się bardzo ważne spotkanie robocze trzech Józefów: Piłsudskiego, Dowbora-Muśnickiego i Hallera. Dotyczyło ono scalenia dowodzonych przez nich jednostek i utworzenia wojska polskiego. Zapadły wówczas niezmiernie istotne dla przyszłości walczącego na kilku frontach o swoje granice państwa decyzje. Jak się wkrótce okazało, połączenie trzech armii i ustanowienie jednolitego nad nimi dowództwa miało ogromne strategiczne znaczenie dla przebiegu

[3] Zachowane do dzisiaj znakomite zdjęcia fotograficzne wykonał podczas pobytu alianckiej Misji Koalicyjnej renomowany poznański zakład fotograficzny Kazimierza Gregera (1887-1967). Tak zwany Album Gregera, na który składają się zarówno zdjęcia plenerowe, jak i atelierowe, stanowi najważniejsze źródło dokumentacji fotograficznej postaci historycznych związanych $\mathrm{z}$ powstaniem wielkopolskim. $\mathrm{W}$ dziedzinie malarstwa analogiczną rolę na odmiennych nieco zasadach pełnią obrazy autorstwa uczestnika powstania wielkopolskiego Leona Prauzińskiego (1895-1940). prowadzonych wówczas operacji i zwycięstwa odniesionego w wojnie polsko-bolszewickiej.

Odnotujmy jeszcze trzydniową jesienną wizytę Józefa Piłsudskiego w dniach 25-27 października 1919 roku w Poznaniu, a następnie w Gnieźnie. Zapoczątkowała ją podróż pociągiem-salonką z Warszawy do Poznania. Trasa do stolicy Wielkopolski wiodła przez Kalisz - Skalmierzyce - Ostrów Wielkopolski - Jarocin i Środę. Od Skalmierzyc Piłsudskiemu towarzyszyli w wagonie: minister byłej Dzielnicy Pruskiej Władysław Seyda, wojewoda poznański Witold Celichowski oraz generałowie Józef Dowbor-Muśnicki i Zygmunt Zieliński.

Zachowało się kilka fotografii z uroczystości patriotyczno-wojskowych, jakie miały miejsce w czasie tej wizyty w Poznaniu. Można na nich zobaczyć nie tylko Piłsudskiego i jego adiutanta pułkownika Bolesława Wieniawę-Długoszowskiego w otoczeniu miejscowych oficjeli, ale także przegląd oddziałów i przejście naczelnika państwa przed frontem prezentujących broń żołnierzy Armii Wielkopolskiej w jej charakterystycznym umundurowaniu.

Warto dodać, iż jedno i drugie zorganizowano w miejscu i entourage'u o symbolicznej wymowie, a mianowicie pod murami byłego zamku cesarskiego. Fotograf przy tym był, zabrakło, niestety, operatora filmowego. O ewentualnym sfilmowaniu tego wydarzenia, podobnie jak o zdjęciach filmowych z uroczystego powitania głowy państwa nazajutrz w Gnieźnie, mimo usilnych kwerend, nie ma w dostępnych źródłach żadnej wzmianki.

Z zachowanych relacji wynika jednoznacznie, iż obfitujący w rozmaite wydarzenia trzydniowy pobyt Józefa Piłsudskiego w Poznaniu pod koniec października 1919 roku żadną miarą nie daje podstaw do twierdzenia, że został on przyjęty w Wielkopolsce chłodno, Wprost przeciwnie, zarówno miasta na trasie przejazdu: Kalisz, Skalmierzyce, Jarocin, Środa Wielkopolska, jak i sam Poznań, a po wyjeździe z niego Gniezno, zgotowały głowie państwa uroczyste przyjęcie.

Ówczesna wizyta Naczelnika Państwa wiązała się ściśle z jego strategicznymi planami włączenia z miesiąca na miesiąc coraz liczniejszych i mających wysoką wartość bojową oddziałów 
wielkopolskich do walk na frontach wojny z wojskami ukraińskimi i bolszewickimi. Piłsudski bardzo potrzebował tego wsparcia i wkrótce je otrzymał. Należy w tym miejscu mocno podkreślić olbrzymi wkład wojenny i wielką daninę krwi Wielkopolan w bojach na ziemiach kresowych: primo - w obronę Lwowa (wyprawa $\mathrm{z}$ ich walnym udziałem niosąca skuteczną odsiecz temu miastu), secundo - w walkach o granice na odcinku północno-wschodnim, tertio - w obronę kraju przed nawałą bolszewicką.

Do niedawna sądzono, że nie istnieje żaden dokumentalny zapis filmowy ilustrujący ów udział. Najnowsza kwerenda w archiwach zagranicznych przyniosła w tej materii ważne odkrycie. W zbiorach francuskich zachowało się wielkiej wartości dokumentalnej unikatowe ujęcie oddziałów Armii Wielkopolskiej z 1919 roku maszerujących przez wieś na kresach wschodnich.

Należy również dodać, iż Piłsudski niewątpliwie doceniał wojenne zasługi jednostek wielkopolskich. Osobiście odebrał pamiętną paradę zasłużonego w bojach o Bobrujsk 55 Poznańskiego Pułku Piechoty (wcześniej 1 Pułku Strzelców Wielkopolskich). Mając w pamięci waleczność pułków dowodzonej przez generała Daniela Konarzewskiego sławnej 14 Dywizji Piechoty Wielkopolskiej w kontrofensywie znad Wieprza, 5 grudnia 1920 roku odznaczył tę doborową jednostkę Krzyżem Orderu Wojennego Virtuti Militari podczas jej stacjonowania w miejscowości Zelwa w powiecie sejneńskim.

Rok później opromieniony zwycięstwem w Bitwie Warszawskiej i pokonaniem bolszewików Józef Piłsudski ponownie przebywał krótko w Kaliszu, dokonując na błoniach tynieckich przeglądu garnizonu kaliskiego i uczestnicząc w uroczystości udekorowania orderem Virtuti Militari sztandaru 29 Pułku Strzelców Kaniowskich z 10 Dywizji generała Lucjana Żeligowskiego, stacjonujących okresowo w tym mieście. Ponadto, zaproszony przez zasłużone dla polskości Kaliskie Towarzystwo Wioślarskie (rok założenia 1887), odwiedził jego siedzibę i odbył przejażdżkę łodzią po Prośnie. Również z tego pobytu brak, niestety, jakiejkolwiek wzmianki o nakręconych zdjęciach filmowych.
W lipcu 1921 roku miał miejsce wielodniowy objazd zachodniej Polski, rozpoczęty trzydniowym pobytem Naczelnika Państwa w Nakle nad Notecią, gdzie w obecności głównodowodzącego wojskiem polskim odbyły się zakrojone na szeroką skalę manewry wojskowe. Piłsudski podróżował tym razem po Wielkopolsce - od Nakła aż po Kępno - automobilem oraz specjalnym pociągiem. Poszukując możliwości nawiązania bliższego kontaktu $\mathrm{z}$ wielkopolskim ziemiaństwem (Bnińscy, Chłapowscy, Turnowie, Mielżyńscy, Koczorowscy, Zamoyscy), odwiedził między innymi Samostrzel, Dębno, Kościan, Rydzynę i podpoznański Kórnik.

W Kępnie Marszałek uczestniczył w ceremonii poświęcenia chorągwi 73 Pułku Piechoty. 9 lipca 1921 roku gościł na rynku w Kórniku i w zamku kórnickim u Władysława Zamoyskiego[4], dziękując za opiekę roztoczoną przez rodzinę Zamoyskich nad przebywającym u schyłku życia w Paryżu jego starszym bratem Bronisławem[5]. Nazajutrz, 10 lipca, wyjechał ze stacji kolejowej w Kórniku do Konina, gdzie, uroczyście fetowany przez tłumy mieszkańców, odebrał defiladę 18 Pułku Piechoty na błoniach nad Wartą, a następnie udał się do Bydgoszczy. Pod koniec tego samego roku Józef Piłsudski raz jeszcze pojawił się w Poznaniu na zaśnieżonym placu Wolności z okazji obchodów trzeciej rocznicy wybuchu powstania wielkopolskiego. Choć istnieją archiwalne fotografie $\mathrm{z}$ tego pobytu, i tym razem również nic nie wiadomo, by uroczystość ta została przez kogokolwiek sfilmowana.

W kolejnym roku, 14 maja, w obecności Naczelnika Państwa odbyło się na poligonie w podpoznańskim Biedrusku poświęcenie i przekazanie chorągwi 74 i 75 Pułku Piechoty, ufundowanych przez społeczeństwo Poznania.

[4] S. Sierpowski, Wizyta Józefa Piłsudskiego w kórnickim zamku w 1921 roku, [w:] Dzieje polityczne, kultura, biografistyka. Studia $z$ historii XIX i XX wieku, red. L. Trzeciakowski, P. Matusik, Poznań 2002, s. 191-199.

[5] Bronisław Piłsudski zmarł w Paryżu 17 maja 1918 roku. Przyczyną śmierci było utonięcie, prawdopodobnie samobójstwo. 
Obie jednostki wyruszały z Biedruska do swoich nowych garnizonów na Górnym Śląsku. Ani jeden operator nie dotarł jednak z kamerą na to wydarzenie, nie dziwi więc brak zdjęć filmowych z jego przebiegu.

W początkach sierpnia 1927 roku Marszałek, zaproszony z żoną i dwiema córkami, był gościem VI Zjazdu Legionistów w Kaliszu, ale na uroczystości odsłonięcia pomnika legionistów w Szczypiornie (7 sierpnia 1927) osobiście się nie pojawił. Po raz kolejny marszałek Piłsudski gościł w Wielkopolsce przejazdem na początku lat trzydziestych podczas wspólnej podróży kolejowej po kraju z prezydentem Ignacym Mościckim. Zastanawiające, iż z żadnego z tych - jak widać całkiem licznych - pobytów, również nie ma żadnych wzmiankowanych w dostępnych źródłach ani też zachowanych rejestracji filmowych.

Obalając podtrzymywany jeszcze tu i ówdzie mit nieobecności Józefa Piłsudskiego w Poznaniu i Wielkopolsce, trzeba jednocześnie wyrazić zdziwienie, iż jego kilkakrotne wizyty nie zostały uwiecznione na taśmie filmowej.

\section{Powstanie bez kamer}

Na podstawie dzisiejszego stanu badań można z dużą dozą prawdopodobieństwa stwierdzić, iż nie istnieje żaden autentyczny zapis filmowy dotyczący bezpośrednio serii najważniejszych wydarzeń historycznych ani działań wojennych powstania wielkopolskiego. Rodzi się pytanie o przyczyny tego stanu rzeczy. Czy dokumentalne obrazy filmowe nie zachowały się do naszych czasów, czy raczej nigdy nie powstały? Sięgnijmy do źródeł filmograficznych, bowiem okazują się one na swój sposób wymowne.

Jeden rzut oka na sporządzony przez prof. Małgorzatę Hendrykowską rejestr materiałów dokumentalnych nakręconych w tamtym okresie na ziemiach polskich uzmysławia, że w przeciwieństwie do innych miast i regionów tematy dotyczące Poznania i Wielkopolski są w nim obecne zaledwie śladowo, a trafniej byłoby powiedzieć niemal całkiem nieobecne. I tak spośród dwudziestu sześciu ogółem zarejestrowanych w roku 1918 materiałów dokumentalnych żaden nie jest związany z tą częścią ziem polskich.
Tylko nieco lepiej przedstawia się sytuacja w następnym roku. Na blisko dziewięćdziesiąt tytułów filmów dokumentalnych należących do produkcji roku 1919 zaledwie pięć (Oswobodzenie Księstwa Poznańskiego, Pobyt Misji Koalicyjnej, Rewia lotnicza w Poznaniu, Obchody święta Trzeciego Maja, oraz Owocna pomoc wojsk poznańskich w walkach o Lwów) ma związek z Wielkopolską. Czy to zupełny przypadek, czy może symptomatyczne świadectwo czegoś więcej? Ten ewidentny brak zainteresowania filmowców terytoriami położonymi nad Wartą, Prosną, Obrą, Brdą i Notecią daje po latach do myślenia.

Aby rzecz głębiej objaśnić, trzeba najpierw uzmysłowić sobie polityczno-administracyjny status tych ziem w momencie zakończenia działań na frontach Wielkiej Wojny w listopadzie 1918 i wkrótce potem, czyli na przełomie lat 1918-1919. Mowa wszakże o specyficznym tworze, którym w okresie po odzyskaniu niepodległości zarządzało Ministerstwo byłej Dzielnicy Pruskiej ze stolicą w Poznaniu i własnym Sejmem Dzielnicowym. Nawykli do spojrzenia w kategoriach dzisiejszych, zapominamy, iż Poznań wraz z Wielkopolską, Śląskiem i Pomorzem w chwili zakończenia wojny i upadku Cesarstwa pozostawał nadal integralną częścią Rzeszy Niemieckiej.

Ów tymczasowy stan pociągał za sobą określone skutki, między innymi w polityce, życiu społecznym, kulturze, gospodarce, porządku prawnym i wojskowości. Na rozległym tle sięgającej początków XIX wieku przeszłości w odniesieniu do Wielkopolski na każdym kroku dawały o sobie znać rozmaite przejawy historycznej autonomii opartej na idei Wielkiego Księstwa Poznańskiego, na straży której - przed utworzeniem zjednoczonego wojska polskiego stał nie naczelnik Piłsudski i rząd w Warszawie, lecz autonomiczna lokalna władza i sformowana w błyskawicznym tempie, w ciągu zaledwie kilku tygodni, oddzielna armia, od 6 stycznia 1919 roku dowodzona przez generała Józefa Dowbora-Muśnickiego.

Czy jesienią 1918 roku Piłsudski wyobrażał sobie przyszłe państwo polskie bez ziem nad 
Wartą? Nie można tego całkiem wykluczyć, w każdym razie w odniesieniu do „wyjściowej” sytuacji z końca 1918 roku, czyli na moment przed wybuchem powstania wielkopolskiego. Autonomia dzielnicowa, czyniąc Poznań i Wielkopolskę bytem w znacznej mierze oddzielnym od reszty kraju, miała swoją gorzką cenę. W momentach przełomowych należało umieć samodzielnie zadbać o siebie, zbiorowy los i własną przyszłość. Braterska pomoc udzielana „z zewnątrz” okazała się niewielka, a w każdym razie, podobnie jak na Śląsku, mniejsza niż oczekiwano.

Niepodległościowy zryw Wielkopolan w grudniu 1918 roku, podobnie jak niebawem w przypadku Ślązaków[6], rychło napotkał na ich zbiorowe poczucie osamotnienia w prowadzonej na wielu lokalnych frontach walce z Niemcami. Wkrótce stało się jasne, że nie ma co czekać na sukurs Warszawy, a powodzenie lub niepowodzenie powstania przeciw Niemcom zależy wyłącznie od skuteczności własnych działań.

\section{Zastępcza ikonografia}

Brak taśm nie oznacza, że mimo wszystko na ekranach i w obiegu społecznym one nie funkcjonują. Z zastępczą ikonografią powstania wielkopolskiego obcujemy od dziesiątków lat, nieświadomie i nieustannie. Wobec całkowitego braku rejestracji filmowych uwaga ta dotyczy w pierwszej kolejności materiałów fotograficznych.

Jak to braku? Przecież wszyscy widzieliśmy co najmniej jedną „dyżurną” fotografię z powitania Paderewskiego. Znamy ją wszyscy. Ileż razy była ona reprodukowana na kartach podręczników szkolnych i w opracowaniach akademickich? Oto przyjeżdżającego do Poznania Ignacego $\mathrm{Pa}$ derewskiego witają przed Dworcem Głównym tłumy. Most Dworcowy jest dosłownie oblepiony tłumem oczekujących na dostojnego gościa ludzi, głowa przy głowie. Owszem, sytuacja taka miała miejsce w rzeczywistości i faktycznie została owego dnia uwieczniona przez fotografa. Tyle tylko, że nie są to zdjęcia wykonane 26 grudnia 1918 roku roku, o czym za chwilę.

Nieporównanie lepiej przedstawia się pod tym względem na przykład stan zasobów archi- walnych dotyczących Górnego Śląska. Mamy tutaj nie tylko Wielkie święto narodowe oraz manifestację ludu ślaskiego na terenie powstańczym (29 czerwca 1921), dalej 400-metrowy materiał Wkroczenie wojsk polskich na Górny Śląsk (1922), nakręcony przez Jana Skarbka-Malczewskiego, ale także zrealizowany (prawdopodobnie przez Alberta Wywerkę) reportaż wojenny Powstanie polskie na Górnym Śląsku, zawierający między innymi sceny wkroczenia oddziałów powstańczych do Tarnowskich Gór.

Ani Poznań, ani Wielkopolska podobnych materiałów filmowych po prostu nigdy nie miały. Jedyne w XX wieku zwycięskie polskie powstanie nie posiada własnej ikonografii dokumentalnej złożonej z ruchomych obrazów. Choć pierwszą rekonstrukcję wydarzeń z 27 grudnia 1918 roku podjęto z myślą o filmie stosunkowo bardzo szybko, bo już w roku 1924.

\section{Sztukowanie historii}

Jakże? powie na to ktoś. Przecież w dziewięciu na dziesięć filmach montażowych dotyczących tematyki odzyskania niepodległości zarówno tych powstałych w czasach PRL, jak i wyprodukowanych współcześnie - pojawia się wykorzystywane niezliczoną ilość razy archiwalne filmowe ujęcie Ignacego Paderewskiego w Poznaniu. To powszechnie znany materiał filmowy z osobistym udziałem pianisty. Nie żadna ad hoc wykonana aktorska inscenizacja, lecz ikonograficzny autentyk.

Czyżby? Na pewno? Identyfikacja sfilmowanej postaci nie budzi najmniejszej wątpliwości: to z całą pewnością Ignacy Jan Paderewski, nikt inny. Zgadza się też pora roku, o czym świadczy nie tylko mglisty pejzaż wokół, lecz również stroje sfilmowanych ludzi. Zarejestrowano kamerą historyczny moment, gdy mistrz wchodzi do Bazaru w towarzystwie małżonki, ubrany ze względu na porę roku na zimowo. Niby wszyst-

[6] Zob. A. Gwóźdź, Bliżej Polski, czyli obrazy powstań śląskich i plebiscytu w polskim filmie. Artykuł złożony do druku na łamach „Kwartalnika Filmowego". Za jego udostępnienie przed publikacją pragnę $\mathrm{w}$ tym miejscu podziękować Autorowi. 
ko z grubsza odpowiada faktom, a jednak coś tu nie pasuje.

Ujęcie jest bardzo krótkie, trwa zaledwie kilkanaście sekund. Nie sposób powątpiewać w jego autentyczność. Nie mamy do czynienia $\mathrm{z}$ aktorem w roli Paderewskiego, bowiem na ekranie ewidentnie pojawia się on we własnej osobie. Co najwyżej lekkie zdziwienie widza budzi zaskakująco pogodna aura emocjonalna zarejestrowanej sceny i coś jeszcze, co natychmiast zauważy znający swoje miasto mieszkaniec Poznania. Paderewski wchodzi po stopniach, tymczasem, jak powszechnie wiadomo, wejście do poznańskiego Bazaru, jest usytuowane na poziomie ulicy, prowadząc prosto z trotuaru Alei Marcinkowskiego. Skąd zatem wzięły się owe zagadkowe schody?

Na wszystkie te pytania mógłby dać wyczerpującą odpowiedź producent tego materiału, poznański przedsiębiorca filmowy, właściciel Filmotwórni Poznańskiej, Stanisław Martynowski. W tamtym czasie (mowa o drugiej połowie roku 1924) kończył on zdjęcia do produkowanego w Poznaniu monumentalnego filmu zatytułowanego Odrodzona Polska. Jego reżyserem był Zygmunt Wesołowski. Integralną część ekranowego widowiska stanowiły reinscenizowane w autentycznych sceneriach miasta epizody z powstania wielkopolskiego (między innymi śmierć Franciszka Ratajczaka, w którego postać wcielił się Jan Woskowski). Brakowało jednakowoż w Odrodzonej Polsce kluczowej historycznej sceny: momentu przybycia Paderewskiego do Poznania w dniu 26 grudnia 1918 roku.

Pomysłowy przedsiębiorca wpadł na pomysł, by sfilmować Mistrza, gdy ten przybędzie do Poznania odebrać doktorat honorowy Uniwersytetu Poznańskiego. Warto tutaj wprowadzić

[7] Nasza hipoteza potwierdziła się w pełni, gdy w podparyskim Bois d’Arcy wspólnie z prof. Małgorzatą Hendrykowską odkryliśmy o wiele lepiej zachowaną kopię tego samego materiału. W tle sfilmowanej sceny z Paderewskim widać wyraźnie zarys zachodniej wieży Zamku Cesarskiego, co potwierdza w całej rozciągłości, iż ujęcie owo zostało wykonane nie przed Bazarem, lecz na schodach Collegium Minus. niezmiernie ważne we wszelkich badaniach historycznofilmowych rozróżnienie na obraz i reprezen tację. Distinguendum est...

Nie tylko w toku prac identyfikacyjnych, ale przede wszystkim w codziennej praktyce komunikowania zachodzącego za pośrednictwem ruchomych obrazów mamy nieustannie do czynienia $\mathrm{z}$ różnymi wariantami relacji i napięć między tym, co obraz realnie zawiera i faktycznie przedstawia, a tym, co umownie reprezentuje wykorzystany i znaczący to czy owo w ramach danego przekazu. Aby rzecz zilustrować, sięgnijmy po konkretny przykład.

23 listopada 1924 roku kamera Martynowskiego zarejestrowała moment wejścia Ignacego Paderewskiego do gmachu Collegium Minus[7]. I właśnie to ujęcie przez kolejne dziesiątki lat funkcjonowało i nadal funkcjonuje w niezliczonych powieleniach jako scena historycznego przyjazdu Mistrza z końca grudnia roku 1918. Dodajmy, iż późnowieczorna pora, o której pociąg przytrzymany przez Niemców na stacji w Rogoźnie, a potem entuzjastycznie witany przez mieszkańców Obornik dotarł w końcu do Poznania, absolutnie wykluczała możliwość wykonania zarówno fotografii, jak i zdjęć filmowych.

Nic więc dziwnego, że z powodu technicznej niewykonalności nie ma nie tylko żadnych zdjęć kinematograficznych, ale też ani jednej fotografii zrobionej przez kogokolwiek $\mathrm{w}$ tamtym historycznym momencie, bo po prostu nie sposób było ją wykonać z powodu panujących o tej porze ciemności. Poczynioną tutaj uwagę można rozciągnąć również na szereg innych wydarzeń dotyczących dziejów powstania wielkopolskiego, zwłaszcza niemożliwych do nakręcenia in statu operandi epizodów bitewnych.

\section{Kwerenda nadziei}

Czekają na swoje odnalezienie i ponowne odkrycie bezcennej wartości zaginione taśmy z tamtego okresu, mniej lub bardziej bezpośrednio powiązane z Poznaniem i Wielkopolską. Wymieńmy tytułem przykładu: Urzędowy Dziennik Polfilmy zawierający bliżej nieokreślone epizody $\mathrm{z}$ walk pod Lwowem oraz sceny odsieczy na ratunek temu miastu przeprowa- 
dzonej przez 7 Pułk Strzelców Wielkopolskich, a także rewię lotniczą na poznańskim lotnisku Ławica $\mathrm{z}$ okazji wspomnianego przez nas wcześniej pobytu Misji Koalicyjnej w marcu 1919 roku. Brakuje także ciągle, być może zachowanego w którymś z archiwów, reportażu filmowego nakręconego przez Jana Skarbka-Malczewskiego z pobytu w Poznaniu alianckiej Misji Koalicyjnej w dniach 1-3 marca 1919 roku. Podobnie jak wcześniej wymienione, miałby on dzisiaj dużą wartość historyczną.

Pora na ostateczną konkluzję. Postawione w tytule tego artykułu pytanie „dlaczego nie ma taśm z powstania wielkopolskiego?" prowadzi nas do udzielenia następujących odpowiedzi.

Odpowiedź pierwsza: nie ma ich dlatego, że na przykład w chwili przyjazdu Paderewskiego, zważywszy na wieczorną porę, generalnie nie było wtedy, czyli w okresie zimowym, odpowiednich warunków oświetleniowych do fotografowania i filmowania.

Odpowiedź druga: na miejscu zdarzenia zabrakło sprzętu filmowego oraz odpowiednio przygotowanych i przedsiębiorczych operatorów.

Odpowiedź trzecia: charakter operacji powstańczych polegający na prowadzeniu działań zaczepnych, rajdach i atakach na pozycje i obiekty niemieckie dokonywanych z zaskoczenia wykluczał z góry możliwość kręcenia zdjęć bezpośrednio na froncie.

Odpowiedź czwarta: w latach 1918-1920 władze centralne skupiały uwagę na uwiecznianiu wydarzeń historycznych nie w Wielkopolsce, lecz w innych regionach kraju, wychodząc z mylnego, co tu kryć, założenia, iż działania wojenne toczone przez oddziały powstańcze o granice zachodnie i północne mają mniejsze znaczenie w porównaniu $\mathrm{z}$ tym, co działo się na wschodnich rubieżach odrodzonego państwa. Materiałów filmowych stamtąd jest wiele.

Odpowiedź piąta: nie jest jednak tak, że absolutnie niczego istotnego wówczas w Poznańskiem nie sfilmowano, o czym informują nas dzisiaj jedynie bardzo nieliczne inseraty prasowe i lokalne informacje o kinowych pokazach.

Odpowiedź szósta: archiwa krajowe i zagraniczne dysponują ciągle jeszcze bardzo zniko- mą liczbą zidentyfikowanych i zachowanych do dzisiaj filmowych materiałów dokumentalnych $\mathrm{z}$ tego okresu.

Dzięki zakrojonym na szeroką skalę intensywnym poszukiwaniom i międzynarodowej kooperacji badaczy i archiwistów wypada jednak mówić o pewnym postępie i konkretnych odkryciach. Można więc dzisiaj obejrzeć na przykład francuskie materiały filmowe ukazujące przyjazd generała Józefa Hallera i oddziałów Błękitnej Armii do Krotoszyna w kwietniu 1919 roku oraz wieloujęciowy reportaż z pobytu francuskiego operatora wytwórni Gaumont w Poznaniu wiosną 1920 roku. Jest zatem lepiej niż niegdyś i jeszcze do niedawna, ale do osiągnięcia pożądanego stanu nasycenia dostępnymi materiałami filmowymi dobrej jakości jeszcze daleko.

Odpowiedź siódma: na pierwszy rzut oka zauważalny w naszych archiwach brak takich dokumentów filmowych nie oznacza, że nie ma ich nigdzie indziej. Należy w związku z tym przeprowadzić gruntowne i systematyczne poszukiwania w filmotekach zagranicznych. Kwerendy przeprowadzone w ciągu ostatnich lat już przyniosły obiecujące rezultaty. Fakt, że prawie nie ma dziś w polskich zasobach archiwalnych kluczowych pod względem ich wartości historycznej zdjęć filmowych z tych ziem, które faktycznie dotyczyłyby tamtego okresu, nie oznacza, że pewnego dnia ich nie odkryjemy.

\section{B I B L I O G R A F I A}

Czubiński A., Wielkopolska w latach 1918-1939, Poznań 2000

Dworecki Z., Poznańskie i Piłsudski, Poznań 2008

Guzek M., Co wspólnego z wojna ma kinematograf? Kultura filmowa na ziemiach polskich $w$ latach 1914-1918, Bydgoszcz 2014

Guzek M., Filmowa Bydgoszcz 1896-1939, Toruń 2004

Hendrykowska M., Historia polskiego filmu dokumentalnego (1896-1944), Poznań 2015

Hendrykowska M., Hendrykowski M., Film w Poznaniu $i$ Wielkopolsce 1896-1996, Poznań 1996

Jędrzejewicz W., Cisek J., Kalendarium życia Józefa Piłsudskiego, t. 1-2, Wrocław 1994

Skaff S., The Law of the Looking Glass. Cinema in Poland 1896-1939, Athens - Ohio 2008 